\title{
Teknik 3M (Meniru-Mengolah-Mengembangkan) Dalam Menulis Teks Berita
}

\author{
Author: \\ Hartati Meylisa Purba ${ }^{1}$ \\ Intan Maulina ${ }^{2}$ \\ Bilferi Hutapea $^{3}$
}

Afiliation:

Universitas Efarina ${ }^{1,2,3}$

Corresponding email

hartatimeylisapurba@gmail.com

Histori Naskah:

Submit: 2021-11-05

Accepted: 2021-11-06

Published: 2021-11-15

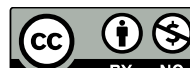

This is an Creative Commons License This work is licensed under a Creative Commons Attribution-NonCommercial 4.0 International License

\begin{abstract}
Abstrak:
Menulis merupakan salah satu keterampilan berbahasa salah satu kegiatan menulis yang membutuhkan stimulus untuk memulai dan menemukan ide adalah kegiatan teks berita. Kesulitan yang dihadapi adalah sulitnya menuangkan ide/gagasan saat menulis sebuah teks berita. Selama ini siswa merasa kesulitan karena tidak diberikan contoh untuk ditiru sebagai pemula dalam menulis teks berita, karena menulis teks berita tidak hanya sesuatu yang langsung ditiru saja namun butuh tahapan mengolah berita tersebut. Tahapan mengolah penting dilakuakn guna mengetahui berita itu apakah akurat, objektif, serta memenuhi syarat praktis penulisan berita yaitu harus ringkas (concise), jelas (clear), dan hangat (current).

Penelitian ini menggunakan jenis penelitian quasi experimental, yang merupakan pengembangan dari true experimental design

Berdasarkan pengamatan, siswa-siswa mengikuti pembelajaran menulis teks berita dengan sungguh-sungguh. Kelas eksperimen mendapatkan teori menulis teks berita, kemudian praktik menulis teks berita dengan menggunakan teknik $3 \mathrm{M}$.

Teknik 3M efektif digunakan dalam pembelajaran menulis teks berita oleh siswa kelas XII SMK Swasta GKPS 2 Pematangsiantar. Hasil penelitian menunjukkan bahwa teknik 3Mmefektif meningkatkan kemampuan menulis teks berita. Teknik ini membantu siswa mengorganisasi ide dan pengetahuan untuk dituangkan dalam tulisan. Siswa kelas eksperimen yang menggunakan teknik 3M dituntut untuk mampu menemukan ide, saling bertukar pendapat, dan memecahkan masalah terkait dengan apa yang diulas.
\end{abstract}

Kata kunci: Teknik 3M, Teks Berita, Metode Belajar

\section{Pendahuluan}

Keterampilan Berbahasa dapat dibentuk dalam lingkungan sekitar, seseorang secara tidak sadar dapat menguasai keterampilan berbahasa melalui menyimak dilanjut dengan berbicara, namun keterampilan menulis dan membaca tidak secara langsung didapatkan dari lingkungan sekitar, melainkan dapat dikembangkan melalui pendidikan yang diperoleh dari lingkungan sekolah. Karena tujuan dasar dari pelajaran Bahasa Indonesia baik di tingkat SD, SMP, maupun SMA adalah terwujudnya keterampilan berbahasa Indonesia yang mencakup empat aspek, yakni (1) keterampilan menyimak (listening skills), (2) keterampilan berbicara (speaking skill), (3) keterampilan membaca (reading skill), (4) keterampilan menulis (writing skill) (Syamsuddin, 1992, hlm. 31). 
Nurgiyantoro (2009: 296) mengemukakan bahwa dibanding tiga kemampuan berbahasa yang lain, kemampuan menulis lebih sulit dikuasai bahkan oleh penutur asli bahasa yang bersangkutan sekalipun. Hal ini disebabkan kemampuan menulis menghendaki penguasaan berbagai unsur kebahasaan dan unsur diluar bahasa itu sendiri yang akan menjadi isi karangan. Namun keterampilan menulis memiliki peranan yang lebih penting dibandingkan keterampilan berbahasa lainnya. Tarigan $(2008,8)$ berpendapat bahwa "dalam kehidupan modern ini, jelas keterampilan menulis sangat di butuhkan". Keterampilan menulis dapat di katakan salah satu ciri dari orang yang terpelajar atau bangsa yang terpelajar. Tolak ukur kecendekiaan seseorang dapat dilihat dari kualitas tulisan-tulisan yang dihasilkannya.

Salah satu keterampilan berbahasa yang diajarkan dalam pembelajaran Bahasa Indonesia adalah menulis. Kegiatan menulis sangatlah bermanfaat untuk meningkatkan kecerdasan dan kreatifitas siswa. Diantara keempat keterampilan berbahasa, keterampilan menulis adalah keterampilan berbahasa yang paling susah dikuasai siswa. Hal ini yang membuat siswa kurang meminati kegiatan menulis ditambah dengan faktor yang diperankan oleh guru kurang memacu semangat siswa untuk menulis. Selama ini guru hanya menggunakan metode ceramah sebagai penyemangat siswa, namun siswa tidak diberikan stimulus yang menjadi contoh atau acuan untuk memulai kegiatan menulis sehingga siswa mengalami kebingungan bahkan ketidaksukaan untuk melakukan kegiatan menulis, yang digunakan untuk berkomunikasi yang berupa penyampaian pesan secara tertulis kepada pihak lain. Aktifitas menulis melibatkan unsur penulis yaitu suatu kegiatan penyampaian pendapat, pesan, gagasan, perasaan, keinginan, dan informasi kedalam bentuk tulisan. Dalam kehidupan modern ini, jelas bahwa keterampilan menulis sangat dibutuhkan. Kiranya tidaklah terlalu berlebihan bila dikatakan bahwa keterampilan menulis merupakan suatu ciri dari orang yang terpelajar atau bangsa yang terpelajar.

Dalman (2014:3) menyatakan, "Menulis merupakan suatu kegiatan komunikasi berupa penyampaian pesan (informasi) secara tertulis kepada pihak lain dengan mengunakan bahasa tulis sebagai alat atau medianya". Aktifitas menulis melibatkan beberapa unsur, yaitu: penulis sebagai penyampaian pesan, isi, tulisan, saluran atau media, dan pembaca. "Menulis merupakan sebuah proses kreatif menuangkan gagasan dalam bentuk bahasa tulis dalam tujuan, misalnya memberitahu, meyakinkan, atau menghibur. Keterampilan menulis tidak akan datang secara otomatis, tetapi harus melalui latihan dan praktik yang teratur".

Menulis merupakan salah satu keterampilan berbahasa salah satu kegiatan menulis yang membutuhkan stimulus untuk memulai dan menemukan ide adalah kegiatan teks berita. Kesulitan yang dihadapi adalah sulitnya menuangkan ide/gagasan saat menulis sebuah teks berita. Selama ini siswa merasa kesulitan karena tidak diberikan contoh untuk ditiru sebagai pemula dalam menulis teks berita, karena menulis teks berita tidak hanya sesuatu yang langsung ditiru saja namun butuh tahapan mengolah berita tersebut. Tahapan mengolah penting dilakuakn guna mengetahui berita itu apakah akurat, objektif, serta memenuhi syarat praktis penulisan berita yaitu harus ringkas (concise), jelas (clear), dan hangat (current).

Standar kompentensi yang harus di penuhi oleh siswa tingkat SMK menurut Kurikulum 2013 adalah kompetensi berbahasa, baik secara lisan maupun tulisan. Kurikulum 2013 ini mengacu pada menulis beraneka ragam teks. Menulis merupakan salah satu kemampuan yang harus dikuasai oleh siswa SMK adalah menulis teks berita, tepatnya pada KD menulis teks berita di kelas XII semester I. Berdasarkan uraian di atas, dapat disimpulkan bahwa kegiatan pembelajaran menulis teks berita yaitu kegiatan menulis yang terdapat teks untuk memperjelas informasi mengenai sesuatu hal sesuai dengan fakta yang terjadi.

Dalam Kurikulum 2013 (K13) menulis merupakan keterampilan yang harus dimiliki seorang siswa. Keterampilan menulis teks berita merupakan salah satu keterampilan menulis siswa yang terdapat di kelas 
XII SMA/Sederajat, dengan Standar Kompetensi: Mengungkapkan informasi dengan bentuk rangkuman, teks berita, slogan/poster dan Kompetensi Dasar Menulis Teks berita secara singkat, padat, dan jelas. Menulis telah dipelajari mulai dari tingkat Sekolah Menengah Pertama hingga Sekolah Menengah Atas, maka seharusnya siswa telah mampu menulis teks berita dengan baik. Namun pada kenyataannya kemampuan menulis teks berita siswa masih rendah. Hal ini terjadi karena masih banyak guru yang mengajari materi pelajaran dengan teknik yang kurang menarik perhatian siswa. Padahal teknik pembelajaran yang di gunakan oleh guru dalam kegiatan mengajar sangat mempengaruhi kemampuan siswa dalam menguasai materi yang di ajarkan, termasuk dalam pembelajaran menulis teks berita. Tidak baku (campuran antara bahasa jawa dan Bahasa Indonesia). Selain penjelasan di atas, rendahnya keterampilan menulis teks berita siswa kelas XII SMK Swasta GKPS 2 Pematangsiantar. Dapat kita lihat juga dari nilai rata-rata kemampuan menulis teks berita yang baru mencapai nilai 65 . Nilai tersebut kurang dari nilai ketuntasan minimal (KKM) yang mencapai 75.

Faktor lain yang mempengaruhi rendahnya keterampilan menulis teks berita pada siswa kelas XII SMK Swasta GKPS 2 Pematangsiantar dikarenakan siswa kurang memahami ejaan-ejaan yang disempurnakan (EYD) dan penggunaan tanda baca. Hal ini terlihat dari hasil pengamatan yang dilakukan, banyak terdapat kesalahan dalam penggunaan huruf kapital, tanda baca, pemenggalan kata dan juga penggunaan kosakata.

Untuk mengatasi masalah yang dialami oleh siswa dalam pembelajaran menulis teks berita, peneliti mengemukakan sebuah teknik pembelajaran yang berguna menumbuhkan motivasi siswa dalam pembelajaran menulis. Teknik pembelajaran yang dimaksud adalah penerapan 3M (Meniru-MengolahMengembangkan), pertama siswa membaca sebuah bacaan contoh teks berita lalu mencatat hal-hal penting dari bacaan teks berita tersebut. Kedua, siswa membahas dan memahami hal-hal penting dari teks berita yang telah mereka catat. Ketiga, siswa mulai mengembangkan sebuah berita dari hal-hal yang sedang terjadi. Teknik pembelajaran 3M (meniru-mengolah-mengembangkan) sudah ada sejak lama, tetapi penggunaan teknik ini dalam pembelajaran kurikulum 2013 masih baru, sehingga diperlukan penelitian perkembangan dan keefektifan. Teknik 3M (meniru-mengolah-mengembangkan) merupakan teknik yang mendorong siswa untuk berpikir, berbicara, dan kemudian menuliskan suatu topik tertentu. Teknik ini memperkenalkan siswa untuk mempengaruhi dan memanipulasi ide-ide sebelum menuangkannya dalam bentuk tulisan (Huda, 2013:218).

Berdasarkan latar belakang yang telah di uraikan di atas, maka peneliti tertarik untuk melakukan suatu penelitian yang tema teknik 3m (meniru-mengolah-mengembangkan) dalam menulis teks berita pada siswa kelas XII SMK Swasta GKPS 2 Pematangsiantar

\section{Studi Literatur}

"Menulis merupakan suatu kegiatan mengekspresikan secara tertulis sebuah gagasan, ide, pendapat, ataupun pikiran dan juga perasaan Tarigan (2009: 5). Dengan menulis dapat menerangkan segala keinginan hati, perasaan, keadaan, mengembangkan daya pikir dan kreativitas siswa. Sebagai siswa hendaknya mampu menuangkan ide, opini dalam bentuk tulisan. Seorang penulis membuat suatu tulisan bermaksud untuk merekam, meyakinkan, melaporkan, atau memberitahukan kepada orang lain. Menurut Pranoto (2004: 9) "Menulis berarti menuangkan buah pikiran kedalam bentuk tulisan atau menceritakan sesuatu kepada orang lain melalui tulisan". Menulis juga dapat diartikan sebagai ungkapan atau ekspresi perasaan yang dituangkan dalam bentuk tulisan. Dengan kata lain, melalui proses menulis kita dapat berkomunikasi secara tidak langsung. 
Menurut Supriadi dalam Dalman (2014:5) bahwa,"Menulis dapat di defenisikan sebagai suatu kegiatan penyampaian pesan (komunikasi) dengan menggunakan suatu proses kreatif yang banyak melibatkan cara berpikir divirgen (menyebar) daripada konvergen (memusat). Dalam hal ini, menulis adalah proses penyampaian informasi secara tertulis berupa hasil kreatifitas penulisnya dengan cara berpikir kreatif, tidak monoton dan tidak terpusat pada satu pemecahan masalah saja. Dengan demikian, penulis dapat menghasilkan berbagai bentuk dan warna tulisan secara kreatif sesuai dengan tujuan dan sasaran tulisannya.

Menulis sama seperti melukis. Penulis memiliki banyak gagasan dalam menuliskannya. Sekalipun secara teknis ada kriteria-kriteria yang dapat diikutinya, tetapi wujud yang akan dihasilkan itu sangat bergantung pada kepiawaian penulis dalam mengungkapkan gagasan. Banyak orang mempunyai ide-ide bagus sebagai hasil dari pengamatan, diskusi, atau membaca.

Dalman (2014: 6) menyatakan bahwa: Sebagai proses kreatif yang berlangsung secara kognitif, dalam komunikasi tulis terdapat empat unsur yang terlibat yaitu:
a. Penulis sebagai penyampai pesan
b. Pesan atau isi tulisan
c. Saluran atau media berupa tulisan
d. Pembaca sebagai penerima pesan

Menurut Suhandang (2004: 103-104) "Berita merupakan pemberitahuan tentang segala peristiwa aktual yang menarik perhatian orang banyak". Sedangkan, menurut Romli (2005: 3) "Berita merupakan sajian utama sebuah media massa di samping opini (views)".

Dari uraian di atas dapat di ambil kesimpulan bahwa teks berita adalah jenis teks narasi yang melaporkan kejadian, peristiwa, atau informasi mengenai sesuatu yang telah atau sedang terjadi.

Dari defenisi tentang teks berita, pada prinsipnya ada beberapa unsur penting yang harus diperhatikan dari defenisi tersebut, yakni:
a. Laporan
b. Kejadian/peristiwa/pendapat yang menarik dan penting
c. Disajikan secepat mungkin (terikat oleh waktu)

Teknik 3M (meniru-mengolah-mengembangkan) merupakan teknik hasil pengembangan dari model copy the master. Secara harafiah, copy the master berasal dari bahasa Inggris yang artinya adalah model untuk ditiru.

Meniru-Mengolah-Mengembangkan merupakan teknik pembelajaran yang didasarkan pada pemahaman bahwa belajar adalah sebuah perilaku sosial. Teknik pembelajaran yang diperkenalkan oleh Albert Bandura, meniru adalah perilaku seseorang yang akan belajar dengan cara mengamati orang lain. Bandura mengatakan perkembangan teori belajar kognitif tidak cukup menjelaskan perilaku pada anak. Ia meyakini jika proses meniru juga bisa berpengaruh terhadap proses belajar khusunya ketika ia melihat eksperimen boneka bobo, di mana seorang anak memperlihatkan perilaku berbeda ketika diperlihatkan sebuah tayangan. 


\section{JBST}

Volume: 1 | Nomor 1 | November 2021 | E-ISSN: 9999-999x | DOI: 10.47709/jbsi.v1i1. 1223

\section{a. Tahap Meniru}

Tahap meniru di awali dengan kegiatan pra menulis yakni dengan membaca teks berita yang dijadikan model. Pada tahap ini siswa akan diberikan satu contoh teks berita yang di jadikan model yang pernah terjadi.

Menurut Sarsito (2010) mengatakan bahwa peniruan (imitation) merupakan suatu proses kognisi untuk melakukan tindakan maupun aksi seperti yang telah dilakukan oleh model dengan melibatkan indera sebagai penerima rangsang dan pemasangan kemampuan persepsi.

b. Tahap Mengolah

Pada tahap mengolah siswa akan mengolah hasil identifikasi dari unsur teks berita. Unsur tersebut adalah $5 \mathrm{~W}+1 \mathrm{H}$ (What, When, Where, Who, Why + How). Dan pada tahap mengolah siswa harus mampu membuat alur urutan-urutan peristiwa yang terjadi.

c. Tahap Mengembangkan

Tahap mengembangkan dilakukan siswa setelah tahap mengolah. Pada tahap ini siswa akan mengembangkan tema baru, mengembangkan tokoh baru dan mengembangkan peristiwa yang terjadi. Menurut Seels \& Richey (Alim Sumarno 2012: 45) pengembangan berarti menterjemahkan atau menjabarkan spesifikasi rancangan kedalam bentuk fitur fisik. Pengembangan secara khusus berarti proses menghasilkan bahan-bahan pembelajaran.

Berdasarkan uraian di atas, maka disimpulkan bahwa model pembelajaran meniru-mengolahmengembangkan yaitu sebelum memulai belajar kita harus memahami permasalahan yang ada dalam sebuah diskusi kelompok dan kemudian menuliskan dalam bahasa sendiri.

Beberapa orang sebelumnya pernah melakukan penelitian diantaranya Rini Subekti yang berjudul Penerapan Teknik Meniru Mengolah Mengembangkan Dalam Peningkatan Kemampuan Menulis Naskah Siswa Kelas VIII SMP MA'ARIF Kalibawang Wonosobo Tahun Pelajaran 2013/2014" bahwa hasil penelitian menunjukkan nilai rata rata pada pratindakan, siklus I, dan siklus II. Nilai rata-rata pada pratindakan sebesar 50 dan menjadi 67 pada siklus I mencapai 77 pada siklus II.

Djoko santoso yang berjudul Penerapan Strategi 3M Meniru Mengolah Mengembangkan untuk meningkatkan kemampuan siswa dalam menulis poster. Bahwa hasil penelitian menunjukkan hasil observasi yang dilakukan di kelas VIII E pada waktu pembelajaran bahasa Indonesia diperoleh hasil bahwa keterampilan menulis siswa kurang memuaskan, hal ini disebabkan karena guru kurang memberikan penekanan materi yang jelas tentang membuat poster. Untuk itu agar dapat meningkatkan keterampilan menulis siswa dalam menyelesaikan soal tentang membuat poster serta untuk tercapai tujuan pembelajaran perlu diadakan perbaikan pembelajaran dengan menerapkan pendekatan metode $3 \mathrm{M}$ (meniru-mengolahmengembangkan). Penerapan pembelajaran membuat poster melalui pendekatan metode $3 \mathrm{M}$ (menirumengolah-mengembangkan) dapat meningkatkan keterampilan menulis siswa dalam menyelesaikan soal membuat poster.

\section{Metode Penelitian}

Penelitian ini menggunakan jenis penelitian quasi experimental, yang merupakan pengembangan dari true experimental design. Menurut Sugiyono (2013: 116), desain quasi experimental memiliki kelas eksperimen 


\section{JBSYJurma A Bathese

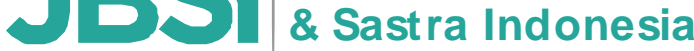

Volume: 1 | Nomor 1 | November 2021 | E-ISSN: 9999-999x | DOI: 10.47709/jbsi.v1i1. 1223

meskipun tidak dapat sepenuhnya berfungsi sebagai pengontrol variable-variabel luar yang mempengaruhi penelitian. Jenis penelitian ini dipilih karena peneliti tidak akan sepenuhnya mampu mengontrol hal-hal yang mempengaruhi variabel penelitian. Menurut Sugiyono (2013: 114), kelompok yang diberi perlakuan disebut kelompok eksperimen

\section{Hasil}

Kegiatan penelitian ini dilaksanakan di kelas XII TKR 1.Penelitian ini dilaksanakan pada 7 Agustus sampai dengan 31 Agustus 2019.Kegiatan penelitian ini dilakukan berdasarkan desain penelitian, yaitu siswa-siswi kelas XII TKR 1 dijadikan sebagai kelas eksperimen yang diberikan pengajaran menulis teks berita dengan menggunakan teknik $3 \mathrm{M}$ (meniru-mengolah-mengembangkan).

Untuk mengukur kemampuan siswa dalam menulis teks berita di kelas, Dilakukan pre tes tanggal 14 Agustus 2019. Selanjutnya, dilakukan post test untuk mengetahui tingkat kemampuan menulis teks berita setelah diberi perlakuan dan sebelum diberi perlakuan. Post test dilaksanakan pada 21 Agustus 2019. Berdasarkan pengamatan, siswa-siswa mengikuti pembelajaran menulis teks berita dengan sungguhsungguh. Kelas eksperimen mendapatkan teori menulis teks berita, kemudian praktik menulis teks berita dengan menggunakan teknik $3 \mathrm{M}$ (meniru-mengolah-mengembangkan).

\section{Data Penelitian}

a. Kemampuan Menulis Teks Berita Kelas Eksperimen

Berikut ini adalah data pretes siswa sebagai berikut:

Tabel 4.1

Data kemampuan menulis teks berita sebelum digunakan teknik pembelajaran $3 \mathrm{M}$ (menirumengolah-mengembangkan)

\begin{tabular}{|c|c|c|}
\hline No. & Nama siswa & Pre-tes \\
\hline 1 & Aldi Blesulri Saragih & 73 \\
\hline 2 & Alpen Aries Girsang & 77 \\
\hline 3 & Aman Sahri Silalahi & 78 \\
\hline 4 & Bonner Damanik & 70 \\
\hline 5 & Breskindo Simarmata & 80 \\
\hline 6 & Deni Janwaldi Hutasoit & 76 \\
\hline 7 & Evan Karunia Purba & 77 \\
\hline 8 & Fernando Christian Hadi Candra Girsang & 70 \\
\hline 9 & Fresman Novaldi Ambarita & 72 \\
\hline 10 & His Givendo Silalahi & \\
\hline
\end{tabular}




\section{JBSYJurma A Bathese}

Volume: 1 | Nomor 1 | November 2021 | E-ISSN: 9999-999x | DOI: 10.47709/jbsi.v1i1. 1223

\begin{tabular}{|c|c|c|}
\hline 11 & Indra Sidabutar & 80 \\
\hline 12 & Jinni Ananda Saragih & 78 \\
\hline 13 & Joy Ariston Pratama Sitopu & 73 \\
\hline 14 & Mikael Simangunsong & 77 \\
\hline 15 & Parulian Siahaan & 64 \\
\hline 16 & Panri Damanik & 72 \\
\hline 17 & Ricky Christian Girsang & 76 \\
\hline 18 & Riski Efianto Siregar & 76 \\
\hline 19 & Rizky Prayuda Sembiring & 75 \\
\hline 20 & Romario Siregar & 65 \\
\hline 21 & Samuel Sahat Sanjaya Purba & 68 \\
\hline 22 & Sinar Samuel Silalahi & 67 \\
\hline 23 & Muhammad Maulana & 1767 \\
\hline 24 & Sandy Agustinus Siringo-ringo & 73,62 \\
\hline & Jumlah & \\
\hline & Rata-rata & 76 \\
\hline
\end{tabular}

Subjek kelas eksperimen sebanyak 24 siswa. Hasil dari pratest kelas eksperimen, yaitu skor tertinggi 80 dan skor terendah sebesar 64. Melalui perhitungan diketahui bahwa skor rata-rata (mean) yang dicapai kelas eksperimen saat pre test sebesar 73,62.

Untuk mengetahui nilai rata-rata pre testdigunakan rumus sebagai berikut

$$
\begin{aligned}
& \mathrm{X}_{1}=\frac{\sum X 1}{n} \\
& \mathrm{X}_{1}=\frac{1767}{24} \\
& \mathrm{X}_{1}=73,62
\end{aligned}
$$

Keterampilan menulis teks berita pada siswa kelas XII TKR 1 SMK Swasta GKPS 2 Pematangsiantar Tahun pelajaran 2019/2020 sebelum diterapkan teknik pembelajaran 3M (meniru-mengolahmengembangkan) sangat kurang dengan nilai rata-rata 73,62.Hal tersebut menunjukkan bahwa kemampuan siswa kurang optimal.Ketidakoptimalan siswa dalam menulis teks berita disebabkan karena teknik yang digunakan dalam pembelajaran masih kurang tepat untuk mendorong kemampuan menulis teks berita. 


\section{JBSYJural Bathase}

Volume: 1 | Nomor 1 | November 2021 | E-ISSN: 9999-999x | DOI: 10.47709/jbsi.v1i1. 1223

Tabel 2

Identifikasi Kecendrungan Hasil Kemampuan Menulis Teks Berita Sebelum Menggunakan Teknik 3M (meniru-mengolah-mengembangkan)

\begin{tabular}{|c|c|c|c|}
\hline Rentang & F.Absolut & F.Relatif & Kategori \\
\hline $85-100$ & 0 & $0 \%$ & Sangat Baik \\
\hline $75-84$ & 13 & $54,1 \%$ & Baik \\
\hline $65-74$ & 10 & $41,6 \%$ & Cukup \\
\hline $55-64$ & 1 & $4,1 \%$ & Kurang \\
\hline $0-54$ & 0 & $0 \%$ & Sangat Kurang \\
\hline & 24 & $100 \%$ & \\
\hline
\end{tabular}

Dari data diatas, diketahui bahwa keterampilan menulis teks berita siswa kelas XII SMK Swasta GKPS 2 Pematangsiantar sebelum diterapkan teknik pembelajaran 3M (meniru-mengolah-mengembangkan) khusus kelas XII TKR 1 termasuk dalam kategori cukup. Hasil nilai kecendrungan tersebut, menunjukkan bahwa keterampilan siswa dalam menulis teks berita sebelum diterapkannya teknik 3M (meniru-mengolahmengembangkan) (pre-test) termasuk kategori sangat kurang, karena dengan nilai rata-rata 73,2 berada pada rentang nilai 65-74 (kurang).

b. Kemampuan menulis teks berita sesudah digunakan teknik $3 \mathrm{M}$ (meniru-mengolahmengembangkan)

Tabel 3

Data Kemampuan Menulis Teks Berita Sesudah Menggunakan Teknik 3M (meniru-mengolahmengembangkan) Penilaian post-test

\begin{tabular}{|c|c|c|}
\hline NO & NAMA SISWA & POS-TES \\
\hline 1 & Aldi Blesulri Saragih & 80 \\
\hline 2 & Alpen Aries Girsang & 81 \\
\hline 3 & Aman Sahri Silalahi & 82 \\
\hline 4 & Bonner Damanik & 85 \\
\hline 5 & Breskindo Simarmata & 85 \\
\hline 6 & Deni Janwaldi Hutasoit & 88 \\
\hline 7 & Evan Karunia Purba & 84 \\
\hline 8 & Fernando Christian Hadi Candra Girsang & \\
\hline
\end{tabular}




\section{JBST}

Volume: 1 | Nomor 1 | November 2021 | E-ISSN: 9999-999x | DOI: 10.47709/jbsi.v1i1. 1223

\begin{tabular}{|c|c|c|}
\hline 9 & Fresman Novaldi Ambarita & 79 \\
\hline 10 & His Givendo Silalahi & 80 \\
\hline 11 & Indra Sidabutar & 89 \\
\hline 12 & Jinni Ananda Saragih & 87 \\
\hline 13 & Joy Ariston Pratama Sitopu & 86 \\
\hline 14 & Mikael Simangunsong & 86 \\
\hline 15 & Parulian Siahaan & 88 \\
\hline 16 & Panri Damanik & 78 \\
\hline 17 & Ricky Christian Girsang & 78 \\
\hline 18 & Riski Efianto Siregar & 83 \\
\hline 19 & Rizky Prayuda Sembiring & 88 \\
\hline 20 & Romario Siregar & 84 \\
\hline 21 & Samuel Sahat Sanjaya Purba & 81 \\
\hline 22 & Sinar Samuel Silalahi & 79 \\
\hline 23 & Muhammad Maulana & 78 \\
\hline 24 & Sandy Agustinus Siringo-ringo & 79 \\
\hline & Jumlah & 1990 \\
\hline & Rata-rata & 82,91 \\
\hline
\end{tabular}

Untuk mengetahui nilai rata-rata post-tes di gunakan rumus sebagai berikut:

Data Post - test

$$
\begin{aligned}
& X_{1}=\frac{\sum X 1}{n} \\
& X_{1}=\frac{1990}{24} \\
& X_{1}=82,91
\end{aligned}
$$

Keterampilan menulis teks berita siswa kelas XII SMK Swasta GKPS 2 Pematangsiantar tahun pelajaran 2019/2020 sebelum diterapkan teknik pembelajaran 3M (meniru-mengolah-mengembangkan) sangat kurang dengan nilai rata-rata 82,91. Hal tersebut menunjukkan bahwa kemampuan siswa kurang optimal, ketidakoptimalan siswa dalam menulis teks berita disebabkan karena model yang digunakan dalam pembelajaran masih kurang tepat untuk mendorong kemampuan menulis teks berita. 


\section{JBS Jural Bathas}

Volume: 1 | Nomor 1 | November 2021 | E-ISSN: 9999-999x | DOI: 10.47709/jbsi.v1i1. 1223

Tabel 4

Identifikasi Kecendrungan Hasil Kemampuan Menulis Teks Berita Setelah Menggunakan Teknik 3M (meniru-mengolah-mengembangkan)

\begin{tabular}{|c|c|c|c|}
\hline Rentang & F.Absolut & F.Relatif & Kategori \\
\hline $85-100$ & 9 & $37,5 \%$ & Sangat Baik \\
\hline $75-84$ & 15 & $62,5 \%$ & Baik \\
\hline $65-74$ & 0 & $0 \%$ & Cukup \\
\hline $55-64$ & 0 & $0 \%$ & Kurang \\
\hline $0-54$ & 0 & $0 \%$ & Sangat Kurang \\
\hline & 24 & $100 \%$ & \\
\hline
\end{tabular}

Dari data diatas, diketahui bahwa keterampilan menulis teks berita siswa kelas XII SMK Swasta GKPS 2 Pematangsiantar setelah diterapkan teknik pembelajaran 3M (meniru-mengolah-mengembangkan) khusus kelas XII TKR 1 termasuk dalam kategori baik. Hasil nilai kecendrungan tersebut, menunjukkan bahwa keterampilan siswa dalam menulis teks berita setelah diterapkannya teknik 3M (meniru-mengolahmengembangkan) (pre-test) termasuk kategori baik, karena dengan nilai rata-rata 82,91berada pada rentang nilai 75-84 (baik).

Tabel 5

Data Nilai Penggunaan Model Pembelajaran 3 M (meniru-mengolah-mengembangkan) Dalam Pembelajaran Menulis Teks Berita Siswa Kelas XII SMK Swasta GKPS 2 Pematangsiantar

\begin{tabular}{|c|l|c|c|c|c|}
\hline NO & \multicolumn{1}{|c|}{ NAMA SISWA } & PRE-TES & POS-TES & D & $\mathbf{D}^{\mathbf{2}}$ \\
\hline 1 & Aldi Blesulri Saragih & 75 & 80 & -5 & 25 \\
\hline 2 & Alpen Aries Girsang & 73 & 82 & -9 & 81 \\
\hline 3 & Aman Sahri Silalahi & 77 & 81 & -4 & 16 \\
\hline 4 & Bonner Damanik & 78 & 82 & -4 & 16 \\
\hline 5 & Breskindo Simarmata & 70 & 85 & -15 & 225 \\
\hline 6 & Deni Janwaldi Hutasoit & 80 & 85 & -5 & 25 \\
\hline 7 & Evan Karunia Purba & 76 & 88 & -12 & 144 \\
\hline 8 & Fernando Christian Hadi C Girsang & 77 & 84 & -7 & 49 \\
\hline 9 & Fresman Novaldi Ambarita & 70 & 79 & -9 & 81 \\
\hline
\end{tabular}




\section{JBST}

Volume: 1 | Nomor 1 | November 2021 | E-ISSN: 9999-999x | DOI: 10.47709/jbsi.v1i1. 1223

\begin{tabular}{|c|c|c|c|c|c|}
\hline 10 & His Givendo Silalahi & 72 & 80 & -8 & 64 \\
\hline 11 & Indra Sidabutar & 80 & 89 & -9 & 81 \\
\hline 12 & Jinni Ananda Saragih & 78 & 87 & -9 & 81 \\
\hline 13 & Joy Ariston Pratama Sitopu & 78 & 86 & -8 & 64 \\
\hline 14 & Mikael Simangunsong & 73 & 86 & -13 & 169 \\
\hline 15 & Parulian Siahaan & 77 & 88 & -11 & 121 \\
\hline 16 & Panri Damanik & 64 & 78 & -14 & 196 \\
\hline 17 & Ricky Christian Girsang & 72 & 78 & -6 & 36 \\
\hline 18 & Riski Efianto Siregar & 70 & 83 & -13 & 169 \\
\hline 19 & Rizky Prayuda Sembiring & 76 & 88 & 12 & 144 \\
\hline 20 & Romario Siregar & 76 & 84 & -8 & 64 \\
\hline 21 & Samuel Sahat Sanjaya Purba & 75 & 81 & -6 & 36 \\
\hline 22 & Sinar Samuel Silalahi & 65 & 79 & -14 & 196 \\
\hline 23 & Muhammad Maulana & 68 & 78 & -10 & 100 \\
\hline 24 & Sandy Agustinus Siringo-ringo & 67 & 79 & -12 & 144 \\
\hline & Jumlah & 1767 & 1990 & -223 & 2327 \\
\hline \multicolumn{2}{|r|}{ Rata-rata } & 73,62 & 82,91 & & \\
\hline
\end{tabular}

Berdasarkan tabel analisa tersebut maka untuk mengetahui penerapan teknik 3M (menirumengolah-mengembangkan) terhadap pembelajaran menulis teks berita siswa kelas XII SMK Swasta GKPS 2 Pematangsiantar dapat diuji dengan menggunakan rumus sebagai berikut:

Nilai rata-rata Pre-Tes dan Pos-Tes

1. Data Pre-Tes

$$
\begin{aligned}
& \mathrm{X}_{1}=\frac{\sum X 1}{n} \\
& \mathrm{X}_{1}=\frac{1767}{24} \\
& \mathrm{X}_{1}=73,62
\end{aligned}
$$

2. Data Pos-Tes

$$
\mathrm{X}_{1}=\frac{\sum X 1}{n}
$$




\section{JBST Jumal Bahase

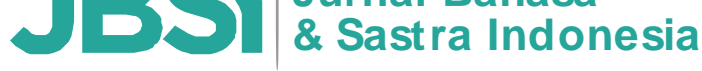

Volume: 1 | Nomor 1 | November 2021 | E-ISSN: 9999-999x | DOI: 10.47709/jbsi.v1i1. 1223

\begin{tabular}{c}
\hline $\mathrm{X}_{1}=\frac{1990}{24}$ \\
$\mathrm{X}_{1}=82,91$
\end{tabular}

Analisis Data

$$
\begin{aligned}
\mathrm{D}^{-} & =\frac{\sum d}{N} \\
& =\frac{-223}{24} \\
& =-9.291
\end{aligned}
$$

Tes signifikansi

$$
\begin{aligned}
& \mathrm{t}=\frac{D^{-}}{\sqrt{\frac{\sum D^{2}-\frac{\sum(D)^{2}}{N}}{N(N-1)}}} \\
& \mathrm{t}=\frac{-9.291}{\sqrt{\frac{2327-\frac{(-223)^{2}}{24(24-1)}}{}}} \\
& \mathrm{t}=\frac{-9.291}{\sqrt{\frac{2327-\frac{4972}{24}}{552}}} \\
& \mathrm{t}=\frac{-9.291}{\sqrt{\frac{2327-207,1}{552}}} \\
& \mathrm{t}=\frac{-9.291}{1.95} \\
& \sqrt{\frac{-9.291}{5.83}}
\end{aligned}
$$




\section{JBST}

Volume: 1 | Nomor 1 | November 2021 | E-ISSN: 9999-999x | DOI: 10.47709/jbsi.v1i1. 1223

$$
\begin{aligned}
& t=-4.76 \\
& \begin{aligned}
d f & =N-1 \\
& =24-1
\end{aligned}
\end{aligned}
$$

$\mathrm{Tt}, 95 \mathrm{df}=23$

T hitung $=-4,76$

Diperoleh t table, maka thitung; -4.76 >, sehingga dapat disimpulkan $\mathrm{H}$ ditolak dan $\mathrm{H}$ diterima. Ini berarti terdapat perbedaan yang signifikan sebelum dan sesudah digunakan teknik pembelajaran $3 \mathrm{M}$ (menirumengolah-mengembangkan).

Data nilai akan disajikan sebagai berikut:

Tabel hasil Pre tes dan Post tes

\begin{tabular}{|c|c|c|c|}
\hline Kelas & \multicolumn{2}{|c|}{ Skor rata-rata } & $\mathrm{D}^{-}$ \\
\hline \multirow{2}{*}{ Eksperimen } & Pre tes & Pos tes & \multirow{2}{*}{$-9,29$} \\
\cline { 2 - 3 } & 73,62 & 82,91 & -29 \\
\hline
\end{tabular}

Pengujian Hipotesis

Hipotesis dari penelitian ini adalah:

a. Ho: Tidak terdapat perbedaan yang signifikan kemampuan menulis teks berita siswa kelas XII SMK Swasta GKPS 2 Pematangsiantar sebelum dan sesudah diterapkan teknik 3M (menirumengolah-mengembangkan).

b. Ha: Terdapat perbedaan yang signifikan kemampuan menulis teks berita siswa kelas XII SMK Swasta GKPS 2 Pematangsiantar sebelum dan sesudah diterapkan teknik 3M (meniru-mengolahmengembangkan).

\section{Pembahasan}

Penelitian ini dilakukan di SMK Swasta GKPS 2 Pematangsiantar, populasi dalam penelitian ini adalah kelas XII, dengan jumlah siswa sebanyak 164 siswa.Sampel dalam penelitian ini berjumlah 24 siswa.Kelas XII TKR 1 sebagai kelas eksperimen.Tujuan penelitian ini adalah untuk mengetahui perbedaan kemampuan menulis teks berita sebelum dan sesudah menggunakan teknik 3M (meniru-mengolah-mengembangkan).

Penelitian ini juga bertujuan untuk mengetahui penerapan teknik meniru-mengolah-mengembangkan dalam pembelajaran menulis teks berita. Dalam pembahasan ini akan dibahas hasil tulisan siswa dalam kategori rendah, sedang, dan tinggi pada kelas eksperimen. 


\section{JBS Jumal ahasesa \& Sastra Indonesia}

Volume: 1 | Nomor 1 | November 2021 | E-ISSN: 9999-999x | DOI: 10.47709/jbsi.v1i1. 1223

Perbedaan Kemampuan Menulis Teks Berita Sebelum dan Sesudah Diberi Pembelajaran Menggunakan Teknik 3 M (meniru-mengolah-mengembangkan)

Teknik 3M efektif digunakan, hal ini dapat dilihat dalam hasil tulisan teks berita. Siswa kelas eksperimen lebih baik dalam mengorganisasi ide, gagasan, dan pikiran yang terkait dengan apa yang di teliti sesudah menggunakan teknik $3 \mathrm{M}$ (meniru-mengolah-mengembangkan). Kelebihan teknik $3 \mathrm{M}$ (menulis-mengolahmengembangkan) dalam menulis teks berita yaitu teknik ini memberi peluang kepada siswa untuk mencatat point-point penting.Kemudian juga memberikan peluang kepada siswa untuk mengembangkan dan memperkaya pengetahuan.

Penjelasan diatas menunjukkan bahwa terdapat perbedaan kemampuan menulis teks berita sebelum dan sesudah menggunakan teknik $3 \mathrm{M}$ (meniru-mengolah-mengembangkan).Berdasarkan penjelasan di atas, dapat diketahui bahwa perbedaan teknik $3 \mathrm{M}$ juga berpengaruh terhadap hasil tulisan siswa.

Penerapan Teknik Meniru-Mengolah-Mengembangkan

Penerapan teknik $3 \mathrm{M}$ dalam pembelajaran menulis teks berita diketahui dengan hasil uji-t untuk sampel berhubungan. Berdasarkan hasil penghitungan, dapat diketahui besarnya nilai $\mathrm{P}$ yaitu 0,05 atau lebih kecil dari taraf signifikansi 5\%. Hasil uji-t sampel berhubungan, menunjukan bahwa terdapat perbedaan keterampilan menulis teks berita yang signifikan sebelum dan sesudah diterapkannya Teknik 3M.

Hasil penelitian ini telah membuktikan bahwa teknik 3M teruji efektif dalam pembelajaran menulis teks berita. Hasil dari penelitian ini mendukung hasil dari penelitian Rini Subekti yang berjudul Penerapan Teknik Meniru Mengolah Mengembangkan Dalam Peningkatan Kemampuan Menulis Naskah Siswa Kelas VIII SMP MA'ARIF Kalibawang Wonosobo Tahun Pelajaran 2013/2014"bahwa hasil penelitian menunjukkan nilai rata rata pada pratindakan, siklus I, dan siklus II. Nilai rata-rata pada pratindakan sebesar 50 dan menjadi 67 pada siklus I mencapai 77 pada siklus II.

Hasil penelitian ini juga mendukung penelitian milik Djoko santoso yang berjudul Penerapan Strategi 3M Meniru Mengolah Mengembangkan untuk meningkatkan kemampuan siswa dalam menulis poster. Bahwa hasil penelitian menunjukkan hasil observasi yang dilakukan di kelas VIII E pada waktu pembelajaran bahasa Indonesia diperoleh hasil bahwa keterampilan menulis siswa kurang memuaskan, hal ini disebabkan karena guru kurang memberikan penekanan materi yang jelas tentang membuat poster. Untuk itu agar dapat meningkatkan keterampilan menulis siswa dalam menyelesaikan soal tentang membuat poster serta untuk tercapai tujuan pembelajaran perlu diadakan perbaikan pembelajaran dengan menerapkan pendekatan metode 3M (meniru-mengolah-mengembangkan).Penerapan pembelajaran membuat poster melalui pendekatan metode 3M (meniru-mengolah-mengembangkan) dapat meningkatkan keterampilan menulis siswa dalam menyelesaikan soal membuat poster.

\section{Kesimpulan}

Dengan demikian, hasil analisis tersebut menunjukkan bahwa teknik 3M (meniru-mengolahmengembangkan) efektif digunakan dalam pembelajaran menulis teks berita oleh siswa kelas XII SMK Swasta GKPS 2 Pematangsiantar.Hasil penelitian pada kelas eksperimen menunjukkan bahwa teknik 3M (meniru-mengolah-mengembangkan) telah teruji efektif dapat meningkatkan kemampuan menulis teks berita.Teknik ini membantu siswa untuk mengorganisasi ide dan pengetahuan untuk dituangkan dalam tulisan.Dari pengamatan peneliti selama proses pembelajaran, proses belajar siswa kelas eksperimen menjadi lebih aktif dibandingkan sebelum menggunakan teknik $3 \mathrm{M}$ (meniru-mengolah-mengembangkan). 


\section{JBST}

Volume: 1 | Nomor 1 | November 2021 | E-ISSN: 9999-999x | DOI: 10.47709/jbsi.v1i1. 1223

Siswa kelas eksperimen yang menggunakan teknik 3M dituntut untuk mampu menemukan ide, saling bertukar pendapat, dan memecahkan masalah terkait dengan apa yang diulas.

\section{Ucapan Terima Kasih (opsional)}

Penulis menyadari bahwa dalam penulisan artikel ini masih sangat jauh dari kesempurnaan baik dari segi penyusunan bahasa maupun dari segi isinya. Maka dari itu penulis sangat mengharapkan kritikan atau saran yang bersifat membangun. Penulis ingin mengucapkan terimakasih yang sebesar-besarnya kepada seluruh dosen Program Studi Bahasa dan Sastra Indonesia di Universitas Efarina yang telah mendidik dan memberikan ilmu pengetahuan yang bermanfaat.

Bapak dan Ibu yang telah sabar dan penuh kasih sayang mendidik, dan mendoakan dengan keikhlasan hati, memberikan semangat, dan mendampingi dalam menggapai cita-cita, juga keluarga dan semua pihak yang tidak mungkin disebutkan disebutkan satu per satu yang telah membantu menyelesaikan artikel ini.

\section{Referensi}

A.R., Syamsuddin. 1992. Studi wacana: teori-analisis-pengajaran. Bandung: Mimbar Pendidikan Bahasa dan Seni FPBS IKIP

Alim Sumarno. 2012. Penelitian Kausalitas Komparatif. Surabaya: elearningunesa.

Asep Syamsul M. Romli, 2005. Jurnalistik Terapan: Suatu Pengantar. Bandung: Batik Press

Burhan, Nurgiyantoro. (2009). Penilaian Pengajaran Bahasa.Yogyakarta: BPFE

H. Dalman, (2014). Keterampilan Menulis. Jakarta: PT. Raja Grafindo Persada.

Huda, Miftahul. 2013. Model-Model PengajarandanPembelajaran. Yogyakarta: PustakaPelajar

Pranoto. (2004). Mengajar Menulis Fiksi untuk Para Guru. Jakarta: Wisma Nugra Sabtana.

Sarsito. (2010). Psikologi remaja. Jakarta: PT Bumi Aksara

Sugiyono. 2013. Metode Penelitian Pendidikan Pendekatan Kuantitatif, Kualitatif, dan R\&D. Bandung: Alfabeta

Suhandang, Kustadi. 2004. Pengantar Jurnalisitik. Bandung: Penerbit Nuansa

Tarigan, Henry Guntur. 2008. Membaca sebagai Suatu Keterampilan Berbahasa. Bandung: Angkasa. 